\section{Tante Marie's Cooking School}

271 Francisco Street, San Francisco, CA 94133, United States of America.

Tel: $\quad$ (1) 4157886699

Email: peggy@tantemarie.com

Website: www.tantemarie.com

Tante Marie's Cooking School, located in San Francisco was founded as a full-time school in 1979. It is one of the first schools of fine cooking offering all-day, year-round classes for people who are serious about cooking well. Graduates from Tante Marie's have interesting and varied careers. In addition to offering professional courses for people wanting to begin a career in culinary or pastry, Tante Marie's welcomes interested avocational students in the Evening Series, Weekend Workshops, One-Day Workshops and Cooking Vacations. There are also cooking parties on weekend evenings where groups of up to 30 people cook together. The emphasis at Tante Marie's is in building confidence in the kitchen.

\section{The Absolute Taste Scholarship}

Purpose: To make candidates learn cooking professionally Eligibility: All prospective students ordinarily resident in the British Isles who are at least 16 years of age and under 25 years of age on commencement of the course

Level of Study: Unrestricted

Type: Scholarship

Value: Up to $100 \%$ of the course fee

Frequency: Annual

Country of Study: United States of America

Application Procedure: Check website for further details

Closing Date: 7 June

Funding: Private

C) Springer Nature Limited 2020

Palgrave Macmillan (ed.), The Grants Register 2021,

https://doi.org/10.1057/978-1-349-95988-4
Additional Information: Please refer to the website for details

For further information contact:

Email: info@tantemarie.co.uk

\section{Tanzania Communications Regulatory Authority (TCRA)}

Tanzania Communications Regulatory Authority (TCRA), Mawasiliano Towers, 20 Sam Nujoma Road, Dar Es Salaam, Tanzania.

Tel:

(255) 222199760 8; 2224120112

Email: dg@tcra.go.tz

Website: www.tcra.go.tz

The Tanzania Communications Regulatory Authority (TCRA) is a quasi-independent Government body responsible for regulating the communications and broadcasting sectors in Tanzania. It was established under the TCRA Act no. 12 of 2003 to regulate the electronic communications, and postal services, and management of the national frequency spectrum in the United Republic of Tanzania.

\section{Tanzania Communications Regulatory Authority ICT Scholarship}

Purpose: The scholarship offers Tanzania students the opportunity to obtain degrees in the Information and Communication Technologies (ICT) and related areas

Eligibility: The scholarship will be awarded on the basis of academic merit and an interview to be conducted by the Scholarship Panel 
Level of Study: Postgraduate

Type: Scholarship

Length of Study: All scholarships are provided for the spec-

ified duration of a particular degree course

Country of Study: Tanzania

Closing Date: 20 July

Funding: International office

Additional Information: Tanzanian students can apply for these ICT scholarships www.tcra.go.tz/images/headlines/ ScholarshipAdvertReadvertisement2015-16.pdf

\section{Tata Trusts}

\section{Lady Meherbai D. TATA Education Trust}

Purpose: The Lady Meherbai D Tata Education Trust awards scholarships to Indian women graduates of recognised universities to pursue higher education abroad, towards the tuition fee Eligibility: Indian women graduates from a recognised university. 1 . Should have a consistently remarkable academic record. 2. Must have applied for admission / secured admission to reputed accredited universities or institutions in the United States, United Kingdom or Europe for the current academic year. 3. Preference will be given to candidates with a minimum of 2 years of work experience in the requisite fields of study

Level of Study: Graduate

Type: Grant

Value: Scholarship amount of ₹600,000 per student is awarded, depending on the performance of candidate

Frequency: Annual

Country of Study: Any country

Application Procedure: Applications have to be processed through mailing process. Application forms will be emailed to the students on request from 11 March to 19 April. Application forms will be emailed to the applicants upon submission of a neatly typed letter / email giving details of: 1 . The course they wish to pursue. 2 . The university they will be attending. 3. The course fee required. 4. Sources of funding. 5. Their current profile along with documents for the same

Closing Date: 26 April

Funding: Private

Additional Information: Students shortlisted for the interviews and scholarships awarded would be solely at the discretion of the Trustees of the Lady Meherbai D Tata Education Trust www.tatatrusts.org/upload/scholarshipannouncement-2019-2020.pdf

\section{For further information contact:}

Bombay House, 24, Homi Mody Street, Mumbai, Maharashtra 400001 , India.
Tel: (91) 2266658282

Email: igpedulmdtet@tatatrusts.org

\section{Te Pôkai Tara Universities New Zealand}

PO Box 11915, Manners Street, Wellington 6142, New Zealand.

Tel: (64) 4043818500

Email: kiri@nzvcc.ac.nz

Website: www.nzvcc.ac.nz

Contact: Kiri Manuera, Scholarships Manager

The New Zealand Vice Chancellors Committee (NZVCC) was established by the Universities Act 1961, which replaced the federal University of New Zealand with separate institutions. Today the Committee represents the interests of New Zealand's 8 universities. The NZVCC represents the interests of the New Zealand university system to government, its agencies and the public through a range of forums and communications from joint consultative groups to electronic and print publications.

\section{William Georgetti Scholarships}

Purpose: To encourage postgraduate study and research in a field that is important to the social, cultural or economic development of New Zealand

Eligibility: Applicants must: a) have resided in New Zealand for a period of at least five years immediately preceding the year of selection; b) be of good moral character and repute; c) be of good health; d) hold a degree of a university in New Zealand or elsewhere or any other academic qualification of a university or other institution of learning (in New Zealand or elsewhere) reasonably equivalent in the opinion of the Scholarship Board to a degree of a university in New Zealand.

Level of Study: Postgraduate

Type: Scholarship

Value: Up to US $\$ 45,000$ per annum

Length of Study: 3 year

Frequency: Annual

Study Establishment: Suitable universities

Country of Study: Any country

Application Procedure: You may apply through the website approximately 8 weeks before applications close.

Closing Date: 1 February 
Funding: Private

Contributor: The Georgetti Trust

Additional Information: Further information is available on request. universitiesnz.communityforce.com/ www.universiti esnz.ac.nz/scholarships/william-georgetti-scholarship

\section{For further information contact:}

Email: scholarshipscf@universitiesnz.ac.nz

\section{Technical University of Denmark (DTU)}

Anker Engelunds Vej 1 Bygning 101A, DK 2800 Lyngby, Denmark.

Tel: (45) 45251156

Email: oerstedpostdoc@adm.dtu.dk

Contact: COFUND secretariat

\section{H.C. Ørsted Fellowships for International Researchers}

Purpose: The Programme will contribute to the researcher's career development, broadening and be deepening individual competencies through exposure to an international and multidisciplinary environment. Eligibility: The programme is open for young talented researchers from all over the world. 1. Level of Study: Research. 2. Type: Fellowships 3. Value: The grant will cover the salary for the postdoc fellow for up to 2 years

Length of Study: 2 years

Country of Study: Denmark

Application Procedure: Applications must be submitted as one compiled PDF file containing all material via DTU's online submission form at www.dtu.dk/english/career

Closing Date: 23 February

Contributor: Marie Sklodowska-Curie Actions

Additional Information: For any queries please contact oerstedpostdoc@adm.dtu.dk www.scholarshipsads.com/16dtu-h-c-orsted-fellowships-international-researchers-2017/

\section{Technische Universiteit Delft (TUD)}

Post bus 5, NL 2600 AA Delft, Netherlands.

Tel: (31) 152789111

Email: info@tudelft.nl

Website: www.tudelft.nl/msc
Founded in 1842, the Delft University of Technology is the oldest, largest, and most comprehensive technical university in the Netherlands. It is an establishment of both national importance and significant international standing. Renowned for its high standard of education and research, TU Delft collaborates with other educational establishments and research institutes, both within and outside of the Netherlands. TU Delft aims at being an, interactive partner' to social issues, committed to answering its multifaceted demands and initiating changes to benefit people in the future.

\section{The Shell Centenary Scholarship Fund, Netherlands}

Purpose: To give students the opportunity to study at the TUD and gain skills that will make a long-term contribution to the further development of their countries

Eligibility: Open to candidates who are nationals of and resident in any country other than the ones listed in, the additional information section below and aged 35 or under, intending to study a subject that will be of significant value in aiding the sustainable development of their home country, fluent in spoken and written English, and neither a current nor former employee of the Royal Dutch/Shell Group of companies

Level of Study: Postgraduate

Type: Scholarship

Value: Full-cost scholarship including tuition fees, international travel, living allowances and health insurance

Length of Study: 2 years

Frequency: Annual

Country of Study: Netherlands

Application Procedure: Applicants must have been admitted to a MSc programme of TU Delft, the International Office will subsequently send you the application form by email, the International Office will check your application on the basis of the Royal Dutch/Shell criteria

Closing Date: 15 December

Contributor: TUD with support from The Shell Centenary Scholarship Fund (TSCSF)

Additional Information: Countries not eligible: Australia, Austria, Belgium, Canada, Cyprus, Czech Republic, Denmark, Estonia, Finland, France, Germany, Greece, Hungary, Iceland, Ireland, Italy, Japan, Latvia, Lithuania, Luxembourg, Malta, The Netherlands, New Zealand, Norway, Poland, Portugal, Slovenia, Slovakia, Spain, Sweden, Switzerland, United Kingdom, and United States

\section{For further information contact:}

Tel: (31) 152785690

Email: msc2@tudelft.nl 


\section{Tel Aviv University (TAU)}

PO Box 39040, Tel Aviv 6997801, Israel.

Tel: $\quad$ (972) 36408111

Email: tauinfo@post.tau.ac.il

Website: www.tau.ac.il

Tel Aviv University (TAU) was founded in 1956 and is located in Israel's cultural, financial and industrial heartland, TAU is the largest university in Israel and the biggest Jewish university in the world. TAU offers an extensive range of programmes in the arts and sciences.

\section{Tel Aviv University Scholarships}

Purpose: To encourage innovative and interdisciplinary research that cuts across traditional boundaries and paradigms Eligibility: Open to candidates who have registered for their Doctoral or Postdoctoral degree

Level of Study: Doctorate, Postdoctorate

Type: Scholarships

Value: Minimum award amount is US\$500

Frequency: Annual

Application Procedure: Applicants can download the application form from the website. The completed application form along with a curriculum vitae and a description of research project with a list of publications is to be sent

Closing Date: 30 April

Additional Information: Applications if sent by email, must be directed to ddprize@post.tau.ac.il international.tau.ac.il/ scholarship_programs

\section{For further information contact:}

The Lowy School for Overseas Students, Center Building, Tel-Aviv University, Israel.

Email: scholarship@tauex.tau.ac.il

\section{Texas LBJ School}

\section{Barbara Jordan Baines Report Fellowship Fund}

Purpose: The Barbara Jordan Baines Report Fellowship Fund is available to students interested in gaining skills in policy writing and storytelling, as well as exercising leadership through managing the student-run publication
Eligibility: The Baines Report Fellowship supports a master's student pursuing skills in writing about public policy and experience in news media and content creation. Preference will be given to applicants with prior writing or journalism experience. All currently enrolled full-time LBJ School Master's students who are in good academic standing are eligible to apply

Level of Study: Graduate

Type: Funding support

Value: Students are eligible up to US\$750 fund and US\$500 toward travel funds

Frequency: Annual

Country of Study: Any country

Application Procedure: Apply using the common Current Student Endowed Fellowship Application form, located on the right side of this page. Students must also submit a current resume, a letter of interest, two writing samples and one wellplanned story idea. Final candidates may be interviewed. For further details, check the following link: lbj.utexas.edu/sites/ default/files/BJBREligCriteria.pdf

Funding: Private

Additional Information: In addition, both the fall and spring fellowship awards provide US\$500 towards travel to attend the Journal of Public and International Affairs (JPIA) reading weekend in February, contingent on JPIA's invitation. JPIA provides main meals and lodging $\mathrm{lbj}$.utexas.edu/lbj-schoolfellowships\#Baines\%20Report

\section{For further information contact:}

Lyndon B. Johnson School of Public Affairs, The University of Texas at Austin, P.O. Box Y, Austin, TX 78713-8925, United States of America.

Tel: $\quad$ (1) 5124713200

Email:1bjdeansoffice@austin.utexas.edu

\section{Elspeth D. Rostow Memorial Graduate Fellowship}

Purpose: The LBJ Foundation is supporting the LBJ School of Public Affairs through the Elspeth Rostow Memorial Fellowship Fund.

Eligibility: To be considered for this fellowship, applicants must be degree-seeking master's students who have completed one year of full-time study at the LBJ School with a cumulative GPA of 3.0 or above. There are no exceptions to these requirements

Level of Study: Graduate

Type: Fellowship

Value: US\$3,000.

Frequency: Annual

Country of Study: Any country 
Application Procedure: 1. Complete the Elspeth D. Rostow Memorial Graduate Fellowship application. 2. Submit a onepage statement describing your public service related commitments since enrolling in the LBJ School. Your statement should describe the needs of the community served, how the project pursued addressed those needs, the role you personally played in the public service activities, and the time commitment of the activity. 3. A current resume.

Closing Date: November

Funding: Private

Additional Information: lbj.utexas.edu/sites/default/files/ RostowCriteria.pdf

\section{For further information contact:}

Email:1bjdeansoffice@austin.utexas.edu

\section{Michael and Alice Kuhn Summer Fellowships}

Purpose: The Kuhn Fellowship grant, made possible by the Michael and Alice Kuhn Foundation, awards each grantee US\$6,000 to cover living expenses during their summer internship

Eligibility: 1. A selection committee will review applications on a rolling basis and recommend applicants with demonstrated commitment to the goals of the Kuhn Summer Fellowship Program: to promote social justice and fight poverty. 2 . Students with diverse backgrounds receive priority consideration. 3 . The selection committee may make requests in addition to the online application, such as official UT transcripts and/or interviews. 4 . The selection committee will make its recommendations to the LBJ School leadership. Final selection is at the discretion of school leadership

Level of Study: Graduate

Type: Fellowship

Frequency: Annual

Country of Study: Any country

Application Procedure: The student's summer work must be done for a nonprofit organization in Central Texas or the United States whose mission is related to social justice and alleviating poverty. There is an interest in supporting students whose placements involve leadership opportunities in the areas of public and legislative advocacy, program-related management, as well as opportunities to work with executive team members on strategic priorities and projects. Students will be asked to link to a Google Drive PDF copy of their: 1. Resume. 2. Relevant three- to five-page writing sample from school or professional setting. 3. Offer letter from the nonprofit confirming the internship and description of work Closing Date: 30 April

Funding: Commercial, Private
Additional Information: lbj.utexas.edu/michael-and-alicekuhn-summer-fellowships

\section{For further information contact:}

Email: LBJFellowships@austin.utexas.edu

\section{Terrell Blodgett Fellowship for Government Services in Urban Management and Finance}

Purpose: The Blodgett Fellowship is awarded annually on a competitive basis as part of the internship fellowship process

Eligibility: The Blodgett Fellowship is awarded annually on a competitive basis as part of the internship fellowship process. First-year master's students pursuing an internship in local government and/or city management are eligible to apply. To be considered for this fellowship, applicants must be degree-seeking master's stundents

Level of Study: Graduate

Type: Fellowship

Frequency: Annual

Country of Study: Any country

Application Procedure: To apply, students must complete the LBJ internship fellowship application and submit it along with their approved internship request form, a letter from the agency supervising the internship, a one-page essay on career goals, and a current resume. Using the following link for further information. www.blodgettfellows.org/

Closing Date: April

Funding: Private

Additional Information: lbj.utexas.edu/sites/default/files/ Blodgett\%20Criteria\%20PDF.pdf

For further information contact:

Email:1bjwriting@austin.utexas.edu

\section{The Community Foundation of South Alabama}

\section{Harry \& Lula McCarn Nurses Scholarship}

Subjects: Nursing Administration or other field of nursing Purpose: To offer financial assistance to a student pursuing a Master's degree in Nursing Administration or a related field. Eligibility: For a student living in Mobile or Baldwin Counties and pursuing a Master's degree in Nursing Administration or other field of nursing in the USA. Applicants must have a minimum 3.0 GPA.

Type: Scholarship 
Study Establishment: University of South Alabama Country of Study: United States of America Additional Information: www.communityfoundationsa.org/ apply-for-a-scholarship

\section{The Foundation for Advancement of Diversity in IP Law}

\section{AIPLEF Sidney B. Williams Scholarship}

\section{Subjects: Law}

Purpose: The Foundation for Advancement of Diversity in IP Law is a charitable organization whose mission is to increase the diversity of the IP bar by providing scholarships and mentoring to underrepresented minority law school students pursuing careers in IP law.

Eligibility: Be enrolled as an entering law school (1L) student. Have proven academic performance at the undergraduate, graduate, and law school levels (if applicable). Have a financial need. Have record of leadership, community activities, and/or special accomplishments. Demonstrate intent to engage in the full-time practice of patent law. Are currently enrolled in or have been accepted to an ABA-accredited law school.

Type: Scholarship

Value: Students will be selected to receive a three-year scholarship of up to US\$30,000 (US\$10,000 per academic year, US\$5,000 per semester, which can only be applied to verifiable costs associated with average tuition and usual fees).

Length of Study: Three years

Country of Study: United States of America

Additional Information: The curriculum of law school as it relates to intellectual property law is not considered in awarding scholarships. Applicants related to a trustee of AIPLEF, a council member of the ABA-IPL Section, Officer or member of the Board of Directors of the AIPLA, or a member of the AIPLEF Scholarship Committee are ineligible to apply. Scholarship recipients are required to attend law school, day or evening, on either a full-time or part-time enrollment basis, and to maintain a grade point average of "B" (3.0) or better. Scholarship recipients are required to join and maintain membership in AIPLA.

\section{The Gerda Henkel Foundation}

\section{Lost Cities Funding Programme}

Subjects: Abandoned cities

Purpose: The aim of the program is to describe the tangible cultures of interpretation, knowledge and perception within these different contexts. Lost Cities are part of a distinct culture of memory, for example, which serves for the negotiation of identities, the preservation of knowledge cultures, the formulation of criticism of progress, or the construction of mythical or sacral topographies as part of a veritable "ruin cult". On this basis, the focus here should not be on the question of which factors led to the city's abandonment. Rather, it is the abandoned cities themselves that are of particular interest, as well as the different forms of their interpretation, instrumentalization and coding in various cultures and time frames.

Eligibility: Eligible to apply are post-doctoral researchers based in a university and working in the area of the humanities and the social sciences. Funding can be provided for projects with a thematic focus being addressed by a group of researchers. The Foundation uses the term "group of researchers" to mean associations of at least two researchers actively involved in the project work which is to be funded by means of scholarships from the Foundation and who are carrying out research into the same issues. Applications can only be made for $\mathrm{PhD}$ or research scholarships. Applications for a research scholarship by the applicant (project leader) are also possible. A maximum total of three scholarships per group of researchers can be applied for, as well as funds for travel and materials. A fundamental prerequisite for a grant is that project staff conduct their own research, which is published under their name. Other contributors who are not financed by scholarships can also be involved in the project. Scholarship applications made by individual researchers outside of the group are not accepted. The funding programme also provides for the project partners to participate in a public "workshop discussion on Lost Cities" organised by the Foundation.

Type: Grant

Value: $€ 2,300$ monthly scholarship, plus a bonus $€ 400$ grant for one child and $€ 100$ for each further child

Length of Study: 36 months

Country of Study: Any country

Closing Date: 2 June

Additional Information: The Foundation generally accepts applications for research projects made by universities, other research institutes or comparable institutions as well as by one or several Postdocs or scholars with Post Doctoral Lecture Qualification. www.gerda-henkel-stiftung.de/en/lost cities

\section{The Lynde and Harry Bradley Foundation}

\section{Grant}

Subjects: Projects may address any arena of public life economics, politics, culture or civil society. As such, support is 
provided to schools of business, economics, public policy and more for activities including research, general operating expenses, graduate and post-graduate fellowships, seminars and speakers programs.

Purpose: Supports projects that "nurture a solid foundation of competent, self-governing citizens, who are capable of and responsible for making the major political, economic and moral decisions that shape their lives."

Eligibility: See website.

Type: Grant

Value: Varies

Country of Study: Any country

Application Procedure: The application process proceeds in two stages. First, brief letters of inquiry are required. If the foundation determines the project to be within its policy guidelines, the applicant will receive a brochure with further application instructions.

Closing Date: 1 March; 1 July; 1 September; 1 December Additional Information: www.bradleyfdn.org

\section{The Marfan Foundation}

Marfan syndrome is a genetic disorder that affects the body's connective tissue. Connective tissue holds all the body's cells, organs and tissue together. It also plays an important role in helping the body grow and develop properly. Connective tissue is made up of proteins. The protein that plays a role in Marfan syndrome is called fibrillin-1. Marfan syndrome is caused by a defect (or mutation) in the gene that tells the body how to make fibrillin-1. This mutation results in an increase in a protein called transforming growth factor beta, or TGF- $\beta$. The increase in TGF- $\beta$ causes problems in connective tissues throughout the body, which in turn creates the features and medical problems associated with Marfan syndrome and some related conditions. Because connective tissue is found throughout the body, Marfan syndrome can affect many different parts of the body, as well. Features of the disorder are most often found in the heart, blood vessels, bones, joints, and eyes. Some Marfan features - for example, aortic enlargement (expansion of the main blood vessel that carries blood away from the heart to the rest of the body) - can be life-threatening. The lungs, skin and nervous system may also be affected. Marfan syndrome does not affect intelligence.

Tel: $\quad$ (1) 5168838712

Email: research@marfan.org

Website: www.marfan.org/

Contact: Josephine Grima, PhD Chief Science Officer The Marfan Foundation 22 Manhasset Avenue Port Washington, NY 11050, United States of America
The Marfan Foundation's mission is to save lives and improve the quality of life of individuals with Marfan syndrome and other genetic aortic conditions. Our values in our mission to save and improve lives, we hold a number of core beliefs and values that drive everything we do: We put families at the heart of what we do. Marfan syndrome and related conditions affect not only individuals but also the people who love them. We stand with and for the whole community.

\section{Faculty Grant Program}

Purpose: The Marfan Foundation is requesting proposals to the Faculty Grant Program which supports two-year grants for basic, translation or clinical research. The grant program is designed to provide financial support for senior faculty members studying any or all disciplines involved in Marfan syndrome, EDS, LDS, and other related disorders. Grant awards are based on proposal evaluation by The Marfan Foundation Scientific Advisory Board with the approval of the Board of Director. The Marfan Foundation will award up to three 2 -year US $\$ 100,000$ grants. We are pleased to announce that one faculty grant will be funded by the Loeys-Dietz Foundation for studies dedicated to Loeys-Dietz syndrome vasculature or TGFBeta.

Eligibility: The principal investigator must hold an MD, $\mathrm{DO}, \mathrm{PhD}, \mathrm{ScD}, \mathrm{DDS}, \mathrm{DVM}$ or equivalent degree. The investigator must have proven ability to pursue independent research as evidenced by original research publications in peer-reviewed journals and should hold a position of Associate Professor or above. Faculty members with less experience who have obtained an NIH R-01 grant are also eligible for the faculty grant award. Work can be performed in the U.S. or internationally and non U.S. appointments are acceptable.

Level of Study: postgraduate

Type: grant

Value: The Marfan Foundation will award up to three 2-year US\$100,000 grant

Frequency: Annual

Country of Study: US

Application Procedure: The application must be submitted electronically, including the application forms, additional pages, and appendices, as a single PDF file, via The Marfan Foundation website, marfan.org. Please name your application using the following format: FacultyGrant_Lastname FirstName.pdf Example: FacultyGrant_Smith_Jane.pdf The application forms may be completed by using the free Adobe Reader program. If you do not already have it, you can download it at www.adobe.com/products/reader.html. The Title Page form requires dated signatures; you may either insert a digital signature and date or print the form and then scan it to include in your application PDF. Additional pages 
should be typed single-spaced using a font size of at least a 10 points and with one inch margins. Pages should be numbered at the bottom. Appendices should not be used to subvert the page limitation on the grant, however, figures, tables, diagrams and photographs can be placed in the appendices. Please present the proposal in the order that follows: THE MARFAN FOUNDATION FACULTY GRANT GUIDELINES 5 1. Title Page: 1 page Application form provided 2. Table of Contents: 1 page Application form provided 3. Project Abstract and Lay Person Summary: 1 page each On a single page, describe precisely and clearly the nature, objective, methods of procedure and significance of the proposed research project, and how it relates to the goal of providing a better understanding of Marfan syndrome, EDS, LDS, and other related disorders and/or improving the treatment or diagnosis of Marfan syndrome, EDS, LDS, and other related disorders (limit 300 words). Rewrite the abstract in abbreviated form in terms suitable for presentation to lay persons (limit 500 words). 4. Research Plan: 3 pages a. Include Goals and Objectives; Rationale; Methodology; Evaluation. (Figures may be placed in appendix if needed). b. Please comment upon the importance of funding: i. Will this funding allow you to pursue studies that would otherwise not be performed? Is funding meant to supplement other sources of support? ii. Do you anticipate that this funding will increase your competitiveness for other funding sources? c. Please comment upon the significance of the work that you propose: i. Is it similar to or a direct extension of work that has been or is being performed elsewhere? ii. Does the work complement or extend other studies that are being performed at your institution? iii. How novel are the studies that you describe? iv. Would such a proposal be competitive for NIH funding in its current form, or would you require additional preliminary data? v. Do you anticipate that the support would lead to the generation of physical resources that might be useful to other investigators in the field? vi. If so, would you be willing to make them widely available? 5 . Budget and Justification List full budget with amount requested. Include: a. Names, titles, time/percentage effort of all participants, requested salaries and fringe benefits and total amount required. b. Statement that the institution or other funding sources will absorb indirect costs. c. A written budget justification. 6 The budget justification should be suited to the proposal. It is important that the investigators match the dollar award with the actual project. If funding from other sources is being used to cover certain parts of the study, please elaborate on what parts of the budget will not be completed with Foundation funding and what the approximate costs of the full project would be. No overhead or indirect costs will be considered. List the additional sources of funding if budget exceeds proposal amount. 6. Other Support: 2 pages List other support received by principal and co-investigators for any projects (include yearly and total budget and duration of any grants): a. Current b. Pending c. Description (in a paragraph, describe each current or pending grant and whether it has scientific or budgetary overlap with the present proposal). 7. Biographical Sketches: 5 pages each Using the supplied form, please provide biographical sketches for key personnel. Indicate the total number of publications in each of the (2) categories: referenced articles and invited works. If you prefer, you may use the NIH biosketch form instead. 8. Facilities Description: 1 page Describe the research facilities (laboratory space, clinical population, etc) available for the project. 9. Appendix a. Figures, tables etc. b. Literature cited c. Human subjects experimental approval d. Vertebrate animal experimental approval Letters of support

\section{Closing Date: 3 April}

\section{For further information contact:}

The application must be submitted electronically, including the application forms, additional pages, and appendices, as a single PDF file, via The Marfan Foundation website, marfan.org.

\section{The National Academies of Sciences, Engineering and Medicine}

\section{Gulf Research Program Science Policy Fellowships}

\section{Subjects: Science policy}

Purpose: Science Policy Fellowships will contribute to leadership development and capacity building by providing recipients with a valuable educational experience at the sciencepolicy interface. Fellows will spend one year on the staff of a state environmental, natural resources, oil and gas, or public health agency; or regional offices of relevant federal agencies in the Gulf region.

Eligibility: Applicants must: Be currently enrolled in a doctoral program or hold an eligible degree, including $\mathrm{MA} / \mathrm{MS}, \mathrm{MPH} / \mathrm{MSPH}, \mathrm{PhD}, \mathrm{ScD}$, EngD, MD, DrPH, and DVM. For applicants not currently enrolled in a doctoral program, eligible degrees must be completed by August 15, 2020, and conferred by December 31, 2020. Applicants currently enrolled in a doctoral program must take a leave of absence for the duration of the fellowship. Come from an area of research including social and behavioral sciences, health sciences and medicine, engineering and physical sciences, earth and life sciences, and interdisciplinary scientific fields relevant to the charge of the Gulf Research Program to focus on "human health and environmental protection including issues relating to offshore oil drilling and hydrocarbon production and transportation in the Gulf of Mexico and on the 
United States" outer continental shelf. Be a U.S. citizen, U.S. national, or lawful permanent resident. Not be currently employed by the U.S. federal government. Full-time, paid, permanent federal employees are not eligible for the fellowship.

Type: Fellowship

Value: Fellows who have completed an MA, MS, or MPH degree or who are currently enrolled in a doctoral program will receive an annual stipend of US $\$ 45,000$. Fellows who have completed a $\mathrm{PhD}, \mathrm{ScD}, \mathrm{MD}$, or $\mathrm{DVM}$ will receive an annual stipend of US $\$ 55,000$. Stipends will be paid directly to the fellow in monthly disbursements.

Frequency: Annual

Country of Study: Any country

Application Procedure: Applications submitted through the online application system.

Closing Date: 4 March

Additional Information: www.nationalacademies.org/gulf/ fellowships-and-grants/science-policy-fellowship

\section{The National GEM Consortium}

\section{MS Engineering Fellowship Program}

Subjects: Engineering

Purpose: The objective of this program is to promote the benefits of a masters degree within industry.

Eligibility: Must be studying disciplines including, but not limited to: Aeronautical Engineering, Aerospace, Agricultural Engineering, Analytical Chemistry, Anatomy, Automotive, Biochemistry, Bioengineering, Biology, Biomedical Engineering, Chemical Engineering, Chemistry, Civil Engineering, Computer Science, Electrical Engineering, Environmental Engineering, Environmental Science, Industrial Engineering, Information Systems, Inorganic Chemistry, Manufacturing Engineering, Materials Engineering, Materials Science, Mathematics, Mechanical Engineering, Metallurgical Engineering, Nuclear Engineering, Operations Research, Organic Chemistry, Petroleum Engineering, Physics, Structural Engineering, Systems Engineering

Type: Fellowship

Value: US\$4,000 living stipend per full-time semester up to 4 semesters (US\$8K per academic year 3 quarters); up to two paid summer internships with a GEM Employer Member; full tuition and fees provided by a GEM University Member

Country of Study: United States of America

Application Procedure: See website.

Closing Date: 15 November

Additional Information: www.gemfellowship.org/students/ gem-fellowship-program/

\section{PhD Engineering Fellowship}

Subjects: Engineering

Purpose: The objective of this program is to offer doctoral fellowships to underrepresented minority students who have either completed, are currently enrolled in a master's in engineering program, or received admittance into a $\mathrm{PhD}$ program directly from a bachelor's degree program.

Eligibility: Fellowships will be awarded to underrepresented minority students who have either completed, are currently enrolled in a master's in engineering program, or received admittance into a $\mathrm{PhD}$ program directly from a bachelor's degree program.

Type: Fellowship

Value: During the first academic year of being awarded the GEM Fellowship, the GEM Consortium remits a stipend and a cost of instruction grant to the institution where the fellow is enrolled. Thereafter, up to the fifth year of the doctoral program, continued financial support of the GEM Fellow is borne by the GEM University through alternative sources of funding such as institutional awards, assistantships or other external fellowships. Fellows recieve US $\$ 16,000$ stipend in the first academic year of the GEM Fellowship; GEM Member University provides a living stipend up to the 5th year of $\mathrm{PhD}$ program, equivalent to other funded doctorate students in the department; a minimum of one paid summer internship with a GEM Employer Member; full tuition and fees at a GEM University Member

Country of Study: Any country Application Procedure: See website.

Closing Date: 15 November

Additional Information: Continued support from the GEM University will be contingent upon the GEM Fellow remaining in good academic standing and making satisfactory progress in their graduate program. Fellows are provided a paid graduate level summer work experience through the Employer Member for at least one summer. www. gemfellowship.org/students/gem-fellowship-program/

\section{PhD Science Fellowship}

Subjects: Chemistry, physics, earth sciences, mathematics, biological sciences, and computer science.

Purpose: The goal of this program is to increase the number of minority students who pursue doctoral degrees in the natural science disciplines

Eligibility: Applicants to this program are accepted as early as their senior undergraduate year, as well as candidates currently enrolled in a Master's of Engineering program and working professionals.

Type: Fellowship

Value: During the first academic year of being awarded the GEM Fellowship, the GEM Consortium remits a stipend and 
a cost of instruction grant to the institution where the fellow is enrolled. Thereafter, up to the fifth year of the doctoral program, continued financial support of the GEM Fellow is borne by the GEM University through alternative sources of funding such as institutional awards, assistantships or other external fellowships. Fellows recieve US\$16,000 stipend in the first academic year of the GEM Fellowship; GEM Member University provides a living stipend up to the 5 th year of $\mathrm{PhD}$ program, equivalent to other funded doctorate students in the department; a minimum of one paid summer internship with a GEM Employer Member; full tuition and fees at a GEM University Member

Country of Study: Any country

Application Procedure: See website.

Closing Date: 15 November

Additional Information: Fellowships offered through this program are portable and may be used at any participating GEM Member University where the GEM Fellow is admitted. www.gemfellowship.org/students/gem-fellowship-program/

\section{The National Hispanic Scholarship Fund}

\section{HSF Scholarship}

\section{Subjects: All}

Purpose: The HSF Scholarship is designed to assist students of Hispanic heritage obtain a university degree.

Eligibility: Must be of Hispanic heritage. Minimum of 2.5 GPA on a 4.0 scale (or equivalent) for graduate students. Must plan to enroll full-time in an accredited, not-for-profit graduate school, in the US. Must complete FAFSA or state based financial aid application (if applicable).

Type: Scholarship

Value: Awards are based on merit; amounts range from US\$500 to US\$5,000, based on relative need, among the Scholars selected.

Country of Study: United States of America

Additional Information: www.hsf.net

\section{The Thomas R. Pickering Foreign Affairs Fellowship Program}

\section{The Thomas R. Pickering Foreign Affairs Fellowship}

Subjects: Public policy, international affairs, public administration, business, economics, political science, sociology, or foreign languages

Purpose: Prepares outstanding young people for Foreign Service careers in the U.S. Department of State. It welcomes the application of members of minority groups historically underrepresented in the State Department, women, and those with financial need.

Eligibility: Must be seeking admission to a two-year, fulltime, on-campus, master's degree program at a U.S.-based graduate institution in an academic field relevant to the work of the Foreign Service. Must have a cumulative grade point average of 3.2 or higher on a 4.0 scale.

Type: Fellowship

Value: US $\$ 37,500$ annually for a two-year period for tuition, room, board, books, and mandatory fees for completion of two-year master's degrees. This includes up to US\$21,500 per year for tuition and mandatory fees and an academic year stipend of US $\$ 16,000$.

Length of Study: Two years

Frequency: Annual

Study Establishment: Howard University

Country of Study: United States of America

No. of awards offered: 30

Closing Date: September

Additional Information: Law degrees do not satisfy this requirement. Fellows are expected to maintain a cumulative GPA of 3.2 throughout their period of study. Applicants apply to two-year graduate programs at U.S.-based universities simultaneously with their application to the Pickering Program. pickeringfellowship.org/

\section{The White House}

\section{Fellowship}

Subjects: All

Purpose: The White House Fellowship is a highly competitive opportunity to participate in and learn about the Federal Government from a unique perspective.

Eligibility: See website.

Type: Fellowship

Value: The work assignment provides the Fellow the opportunity to observe closely the process of public policy development and to come away with a sense of having participated in the governmental process as well as having made an actual contribution to the business of government.

Country of Study: Any country

Closing Date: 1 February

Additional Information: Fellows typically spend a year working as full-time, paid special assistants to senior White House Staff, the Vice President, Cabinet Secretaries and other top-ranking government officials. Fellows also participate in an education program consisting of roundtable discussions with renowned leaders from the private and public sectors, and trips to study U.S. policy in action both domestically and internationally. 


\section{Third World Academy of Sciences (TWAS)}

TWAS Executive Director ICTP Enrico Fermi Building, Room 108, Via Beirut 6, 34151 Trieste Italy.

Tel: $\quad$ (39) 402240327

Email:_edoffice@twas.org

Website: www.twas.org

Contact: Professor Romain Murenzi, Executive Director

The Third Word Academy of Sciences (TWAS) is an autonomous international organization that promotes and supports excellence in scientific research and helps build research capacity in the South.

\section{Council of Scientific and Industrial Research/ TWAS Fellowship for Postgraduate Research}

Purpose: To enable scholars from developing countries (other than India) who wish to pursue postgraduate research to undertake research in laboratories or institutes of the CSIR

Eligibility: Candidates must have a Master's or equivalent degree in science or engineering and should be a regular employee in a developing country (other than India) and be holding a research assignment

Level of Study: Postgraduate

Type: Fellowship

Value: Monthly stipend to cover for living costs, food and health insurance

Length of Study: Up to 4 years

Frequency: Annual

Study Establishment: CSIR research laboratories or institutes

Country of Study: India

Application Procedure: One copy of the application should be sent to TWAS and three copies to CSIR. Application forms are available on request or from the website

Closing Date: 11 May

Funding: Government

Contributor: CSIR (India), the Italian Ministry of Foreign

Affairs and the Directorate General for Development Co-operation

No. of awards given last year: 8

Additional Information: CSIR is the premier scientific organization of India, and has a network of research laboratories covering wide areas of scientific and industrial research twas.org/opportunity/twas-csir-postgraduate-fellowship-pro gramme

\section{For further information contact:}

International S\&T Affairs Directorate, Council for Scientific and Industrial Research (CSIR), Anusandhan Bhavan, 2 Rafi Marg, New Delhi, Delhi 110001, India.

Tel: $\quad$ (39) $0402240314,(91) 1123316751$

Fax: (91) 1123710618 , (39) 0402240689

Email: fellowships@twas.org, jaipal@csir.res.in

\section{OWSD PhD Fellowships for Women Scientists}

Purpose: The PhD fellowship for women scientists from Science and Technology Lagging Countries (STLCs) supports them to undertake $\mathrm{PhD}$ research in the Natural, Engineering and Information Technology sciences at a host institute in the South.

Eligibility: The OWSD PhD Fellowship is offered only to women candidates. 1. Candidates must confirm that they intend to return to their home country as soon as possible after completion of the fellowship.

Level of Study: Postgraduate

Type: Fellowship

Length of Study: Up to 4 years

Frequency: Annual

Closing Date: 31 May

\section{The Council of Scientific and Industrial Research/ TWAS Fellowship for Postdoctoral Research}

Purpose: To enable scholars from developing countries (other than India) who wish to pursue postdoctoral research to undertake research in laboratories or institutes of the CSIR Eligibility: The minimum qualification requirement is a $\mathrm{PhD}$ degree in science or technology. Applicants must be regular employees in a developing country (but not India) and should hold a research assignment. Be a maximum age of 45 years on December 31st of the application year

Level of Study: Postdoctorate

Type: Fellowship

Value: Monthly stipend to cover for living costs, food and health insurance

Length of Study: Up to 12 months

Frequency: Annual

Study Establishment: CSIR research laboratories or institutes

Country of Study: India

Application Procedure: Applicants must complete an application form, available on request or from the website

Closing Date: 11 May

Funding: Government 
Contributor: CSIR (India), the Italian Ministry of Foreign Affairs and the Directorate General for Development Co-operation

No. of awards given last year: 4

Additional Information: CSIR is the premier civil scientific organization of India, which has a network of research laboratories covering wide areas of industrial research twas.org/ opportunity/twas-csir-postdoctoral-fellowship-programme

\section{For further information contact:}

Tel: $\quad$ (39) $0402240314,(91) 1123316751$

Fax: (91) 1123710618 , (39) 0402240689

Email: fellowships@twas.org,jaipal@csir.res.in

\section{TWAS-SN Bose Postgraduate Fellowship Programme}

Eligibility: 1 . be a maximum age of 35 years on 31 December of the application year; 2 . be nationals of a developing country (other than India); 3. must not hold any visa for temporary or permanent residency in India or any developed country; 4. hold a Masters Degree in physics, mathematics or physical chemistry. S/He must have completed at least a total 5 years of undergraduate and postgraduate studies in a recognized university or institute. 5. provide evidence of proficiency in English, if medium of education was not English; 6. provide evidence that $\mathrm{s} /$ he will return to her/his home country on completion of the fellowship; 7. not take up other assignments during the period of her/his fellowship; 8 . be financially responsible for any accompanying family members.

Level of Study: Postgraduate

Type: Fellowship

Length of Study: 5 years

Frequency: Annual

Study Establishment: S.N. Bose National Centre for Basic Sciences

Closing Date: 1 June

For further information contact:

Tel: $\quad$ (91) 3323355706

Fax: (91) 3323353477

Email: deanap@bose.res.in, studentsprogramme@boson. bose.res.in

\section{Thomson Foundation}

37 Park Place, Cardiff, CF10 3BB, United Kingdom.

Tel: $\quad$ (44) 2920353060

Email:_enquiries@thomfound.co.uk
Website: www.thomsonfoundation.co.uk

Contact: Mr Gareth Price

The Thomson Foundation provides practical, intensive training both in the United Kingdom and abroad, along with a wide range of consultancies to journalists, managers, technicians and production staff in television, radio and the press.

\section{Thomson Foundation Scholarship}

Purpose: To enable recipients to attend Thomson Foundation training courses in Britain

Eligibility: Open to professional journalists and broadcasters with at least 3 years of full-time experience

Level of Study: Professional development

Type: Scholarship

Value: Varies

Length of Study: Varies, usually a 12-week Summer course or a shorter 4-week course

Study Establishment: The Thomson Foundation

Country of Study: United Kingdom

Application Procedure: Applicants must complete an application form, available from the Foundation, for the courses they wish to apply for

No. of awards offered: 20

Closing Date: 15 April

Funding: Government, Private

Contributor: The British Foreign Office Chevening Scholarship Scheme

No. of awards given last year: 6

No. of applicants last year: 20

Additional Information: Annual 3-month courses in television, radio and press journalism run from June to September Webpage not open

For further information contact:

Email: enquiries@thomsonfoundation.org

Thurgood Marshall College Fund (TMCF)

901 F Street NW, Suite 300, Washington, DC 20004, United States of America.

Tel: $\quad$ (1) 2025074851

Email: info@tmcfund.org

Website: www.thurgoodmarshallfund.org 
The Thurgood Marshall College Fund (TMCF) was established in 1987 to carry on Justice Marshall's legacy of equal access to higher education by supporting exceptional merit scholars attending America's public historically Black colleges and universities. More than 5,000 Thurgood Marshall Scholars have graduated and are making valuable contributions to science, technology, government, human service, business, education and various communities

\section{Center for Advancing Opportunity Doctorial Fellowship}

Subjects: Education, criminal justice, and entrepreneurship Purpose: CAO supports faculty and students at Historically Black Colleges and Universities (HBCUs) and other postsecondary institutions to develop research-based solutions to the most challenging issues. Our constituency is people living in fragile communities and they are members of all races, ethnicities, and religions.

Eligibility: Must be a current doctoral student at an accredited college or university. Must have received a four-year undergraduate degree from an $\mathrm{HBCU}$, have a current cumulative grade point average of 3.0 or higher, be able to demonstrate leadership abilities and be able to demonstrate a financial need.

Type: Fellowship

Value: Scholars will be selected to receive a scholarship up to US $\$ 15,000$ for the academic school year (US\$7,500 per semester which can only be applied to verifiable costs associated with average tuition and usual fees).

Study Establishment: A Historically Black College and University (HBCU).

Country of Study: United States of America

No. of awards offered: Up to five

\section{CVS Health Pharmacy Scholarship}

Purpose: To offer financial assistance to outstanding students attending one of the three pre-selected publicly-supported Historically Black College and University (HBCU) and Predominantly Black Institution (PBI) Pharmacy Schools within the TMCF 47 member-school network.

Eligibility: Must be enrolled as a full-time graduate or doctoral student. Must have a current grade point average of 3.0 or higher. Must demonstrate outstanding financial need and must demonstrate leadership ability through a variety of measures.

Type: Scholarship

Value: One-year scholarship up to US $\$ 5,000$ for the 2020 Spring and 2020 Fall semester which will be used to cover the costs of tuition and fees, on-campus room and board, and required textbooks purchased from member schools.
Study Establishment: Florida A \& M University, Pharmacy School; University of Maryland Eastern Shore, Pharmacy School; and Texas Southern University, Pharmacy School.

Country of Study: United States of America

Additional Information: The recipient must be willing to apply for a CVS Health Summer internship.

\section{Thurgood Marshall College Fund Scholarships}

Purpose: To financially support outstanding students Eligibility: Open to candidates who are academically exceptional in the creative and performing arts requiring financial help

Type: Scholarship

Value: Varies

Frequency: Annual

Application Procedure: Completed applications must be submitted along with the required attachments

Closing Date: 30 March

Funding: Foundation

Additional Information: Refer to the website for details: tmcf.org/our-scholarships/current-scholarships www.tmcf. org/students-alumni/scholarship/tmcf-all-around-scholarship/

\section{For further information contact:}

AIPLEF Scholarship, 80 Maiden Lane, Suite 2204, New York, NY 1138, United States of America.

Email: jessica.barnes@tmcfund.org

\section{WGRG Foundation Terri Grier Memorial Scholarship}

Subjects: Public policy, public administration, political science, community engagement or other advocacy disciplines. Purpose: To offer financial aid towards books, tuition and/or other college expenses.

Eligibility: Must be a member of an ethnic minority group: African-American (Black), Asian and Pacific Islanders, Hispanic/Latin (Black, White or Asian), Indians (Western and Eastern). Must be a high school senior and/or enrolled in an accredited college or university in the year of the award; demonstrate a 3.0 or higher GPA; demonstrate leadership skills through participation in community/public service, issue advocacy, research, extracurricular, and/or other activities; demonstrate the courage of conviction, persistence, and determination in the pursuit of his or her goals; and demonstrate a commitment to a career in government or the nonprofit and advocacy sectors.

Type: Scholarship 
Value: At least US $\$ 5,000.00$ towards your books, tuition and/or other college expenses.

Country of Study: United States of America

Application Procedure: Must: complete the online application form; select one individual to complete a reference survey to be submitted by either an educator/college professor, administrator, counselor, employer, or individual with significant knowledge of the applicant's experience and public service engagement; provide an official and recent academic transcript with cumulative grade point average and a class standing/rank; submit a personal essay - in your essay, please answer the question directly in the application.

\section{Toxicology Education Foundation (TEF)}

626 Admiral Drive, Ste. C, PMB 221, Annapolis, MD 21401, United States of America.

Tel: $\quad$ (1) 4433214654

Email: tefhq@toxedfoundation.org

Website: www.toxedfoundation.org

The mission of TFE is to encourage, support and promote charitable and educational activities that increase the public understanding of toxicology.

\section{Alleghery-ENCRC Student Research Award}

Purpose: To support a student's thesis, dissertation and summer research project in toxicology and to encourage them to formulate and conduct meaningful research

Eligibility: Open to students who are members in good standing of AE-SOT. The student's advisor must also be a member in good standing and submit a letter concerning availability

Level of Study: Graduate

Type: Award

Value: Up to US $\$ 1,000$

Frequency: Annual

Country of Study: United States of America

Application Procedure: Applicants must send four copies of completed application form along with a project description and budget

Closing Date: 30 May

\section{For further information contact:}

CDC/NIOSH MS 2015, 1095 Willowdale Road, Morgantown, WV 26505, United States of America.

Email: LBattelli@cdc.gov

\section{Colgate-Palmolive Grants for Alternative Research}

Purpose: To identify and support efforts that promote, develop, refine or validate scientifically acceptable animal alternative methods to facilitate the safety assessment of new chemicals and formulations

Level of Study: Research

Type: Research grant

Value: Plaque and maximum award of US $\$ 40,000$

Frequency: Annual

Country of Study: United States of America

Application Procedure: Application is available online. A research plan, budget, curriculum vitae and a letter from the institution must be sent

Closing Date: 9 October

Funding: Private

Contributor: Colgate-Palmolive

No. of awards given last year: 5

Additional Information: www.toxicology.org/awards/sot/ awards.aspx?AwardID =79

\section{Food Safety SS Burdock Group Travel Award}

Purpose: To cover travel expenses for a student to attend the Annual Meeting

Eligibility: Open to full-time graduate students with research interests in toxicology. Students in their early graduate training, who have not attended any SOT Annual Meeting are encouraged to apply

Level of Study: Graduate

Value: Up to US $\$ 500$

Frequency: Annual

Country of Study: United States of America

Application Procedure: Applicants must send a letter of request indicating that he/she is enroled in good standing in a doctoral training programme. The applicant must also state how the research and training relate to food safety

Closing Date: 24 February

For further information contact:

Email:rmatulka@burdockgroup.com

\section{Regulation and Safety SS Travel Award}

Purpose: To help defray the costs of travel to the SOT meeting

Eligibility: Open to students submitting a poster or making a presentation at the SOT meeting

Type: Travel award

Value: US $\$ 1,500$ each

Frequency: Annual 
Country of Study: United States of America

Application Procedure: Applicants must fill an application form and an abstract of work preserved

Closing Date: 15 December

For further information contact:

Email: jtmacgror@earthlink.net

\section{Robert L. Dixon International Travel Award}

Purpose: To financially assist students studying in the area of reproductive toxicology

Eligibility: Open to applicants enroled full-time in a $\mathrm{PhD}$ programme studying reproductive toxicology and are student members of SOT

Level of Study: Doctorate, Graduate

Type: Award

Value: Includes a stipend of US\$2,000 for travel costs to enable students to attend the International Congress of Toxicology meeting

Frequency: Every 3 years

Country of Study: United States of America and abroad

Application Procedure: Applicants must submit a completed application form, reference letter, graduate transcripts and lists of complete citations of the original work

Closing Date: 9 October

Contributor: Toxicology Education Foundation

Additional Information: toxedfoundation.org/travel-awards/

\section{Transport Research Laboratory}

Old Wokingham Road, Crowthorne, Berkshire, RG11 6AU, United Kingdom.

Contact: Research Division

\section{A Master of Science Degree Scholarship}

Purpose: To financially support postgraduate study Eligibility: Open to part-time self-financing students only. Applicants must have applied for a place for graduate study at UCL

Level of Study: Postgraduate

Type: Scholarship

Value: United Kingdom/European Union tuition fees

Length of Study: Full time: 1 year, Part time: 2-3 years

Frequency: Annual

Study Establishment: University College London

Country of Study: United Kingdom
Application Procedure: Applicants should contact the department. If the applicants have not applied to UCL they complete a graduate application form and enclose it with the scholarship application

For further information contact:

Tel: (44) 2072883548

Fax: (44) 2072883322

Email: p.taylor@chime.ucl.ac.uk

\section{Tropical Agricultural Research and Higher Education Center (CATIE)}

7170 Cartago, Turrialba 30501, Costa Rica.

Tel: $\quad$ (506) 25582000

Email: posgrado@catie.ac.cr

Website: www.catie.ac.cr

Contact: Dean of the Graduate School

The Tropical Agricultural Research and Higher Education Center (CATIE) is an international, non-profit, regional, scientific and educational institution. Its main purpose is research and education in agricultural sciences, natural resources and related subjects in the American tropics, with emphasis on Central America and the Caribbean.

\section{Scholarship Opportunities Linked to CATIE}

Purpose: To develop specialized intellectual capital in clean technology, tropical agriculture, natural resources management and human resources in the American tropics

Eligibility: Priority is given to citizens of Belize, Guatemala, El Salvador, Honduras, Nicaragua, Panama, Costa Rica, Mexico, Venezuela, Colombia, the Dominican Republic, Bolivia and Paraguay

Level of Study: Doctorate, Postgraduate

Type: Scholarship

Value: Tuition and fees

Length of Study: 2 years for a Master

Frequency: Annual

Country of Study: Costa Rica

Application Procedure: Applicants must undertake an admission process that constitutes $75 \%$ for curricular evaluation and $25 \%$ for a domiciliary examination. Please refer to the CATIE website for full instructions

No. of awards offered: 350

Funding: Government, Private, Foundation, International office 
Contributor: ASDI, OAS, CATIE, DAAD, CONACYT (Mexico), Ford Foundation, Kellogg Foundation, Joint/ Japan World Bank. USAID provided the original donation for the endowment financing the Scholarship-Loan Program, SENACYT and Belgium Cooperation

No. of awards given last year: 32 in the Scholarship-Loan Program. Over 25 students received funding from alternative sources

No. of applicants last year: 350

\section{Trust Company}

Level 15, 20 Bond Street, GPO Box 4270, New South Wales, Sydney, NSW 2001, Australia.

\section{Miles Franklin Literary Award}

Purpose: To reward the novel of the year that is of the highest literary merit and presents Australian life in any of its phases Eligibility: Refer to the application form. The novel must have been first published in any country in the year preceding the award. Biographies, collections of short stories, children's books and poetry are not eligible. All works must be in English Level of Study: Unrestricted

Type: Award

Value: AU\$60,000

Frequency: Annual

Country of Study: Any country

Application Procedure: Applicants must complete an application form and send six copies of their novel

Funding: Trusts

Contributor: The estate of the late Miss SMS Miles Franklin

No. of awards given last year: 1

Additional Information: If there is no novel worthy of the prize, the award may be given to the author of a play. Please refer to the website for further details: www.milesfranklin. com.au/

\section{For further information contact:}

Email: trustawards@thetrustcompany.com.au

\section{Tu Delft}

Justus \& Louise van Effen Excellence Scholarships

Purpose: The Foundation Justus \& Louise van Effen was established with the aim of stimulating excellent international
MSc students and financially supporting them in their wish to study at TU Delft

Eligibility: Excellent international applicants (conditionally) admitted to one of the 2-year Regular TU Delft's MSc programmes. With a cumulative grade point average (GPA) of $80 \%$ or higher of the scale maximum in the bachelor's degree from an internationally renowned university outside The Netherlands

Level of Study: Graduate

Type: Scholarship

Value: $€ 30.000$ per year for Non-EU students and $€ 11.500$ per year for EU/EFTA students

Frequency: Annual

Country of Study: Any country

Application Procedure: Apply it online. Check with the below link for further information. www.tudelft.nl/en/educa tion/admission-and-application/msc-international-diploma/1admission-requirements/

Closing Date: 1 December

Funding: Private

Additional Information: Membership to the Scholarship club giving access to personal development, workshops, seminars, etc www.tudelft.nl/en/education/practical-matters/schol arships/justus-louise-van-effen-excellence-scholarships/

\section{For further information contact:}

Postbus 5, NL 2600 AA Delft, Netherlands.

Tel: $\quad$ (31) 152789111

Email: info@tudelft.nl

\section{Turkiye Scholarships Burslari}

\section{Turkey Government Scholarships}

Purpose: Winning this Turkish scholarship gives the chance to experience a 4-year undergraduate, master or doctoral program at the partner Turkish Universities and that too in English

Eligibility: 1. There is also a strict criterion when it comes to the age of the applicant. 2. For the undergraduate degree, the candidates should not be born earlier than January 1997. 3. While for Master's degree the candidates must not be born before January 1988. For PhDs the date is January 1983 and for Research program the applicants should be born before January 1973. 4. 70\% marks required for the application of an undergraduate program. 5. 75\% marks required for the application of $\mathrm{PhD}$ and Masters. 6. 90\% marks required for the application of Medical School programs. 7. Anyone holding Turkish citizenship or having 
previously held Turkish citizenship cannot apply for the program. 8. Students who are already studying in Turkey are not able to apply for the Scholarship. 9. Students who are selected must present their documents if they are asked otherwise they will not be entertained

Level of Study: Doctorate

Type: Scholarship

Value: Free Accomodation, No tuition fees, Health expense, Travel Expenses, Language Course Requirement.

Frequency: Annual

Country of Study: Any country

Application Procedure: Turkey scholarship will be applied with the following terms. 1. University Entrance Exam Grade.
2. Diploma Grade. 3. Average Grades. 4. High School Graduation. 5. International Test Score. 6. CGPA

Closing Date: 20 February

Funding: Private

Additional Information: Türkiye Scholarships applications will be received in one period, and applications will be open between 15 January- 20 February for international students from all countries www.turkiyeburslari.gov.tr/en/announce ment/turkiye-scholarships-2020-applications-open

\section{For further information contact:}

Email: intoffice@agu.edu.tr 